\section{РОЛЬ УПРАВЛЯЮЩИХ \\ ОРГАНИЗАЦИЙ \\ В ПРОВЕДЕНИИ САНИТАРНО- ПРОТИВОЭПИДЕМИОЛОГИЧЕСКИХ МЕРОПРИЯТИЙ \\ ПО ПРЕДУПРЕЖДЕНИЮ \\ РАСПРОСТРАНЕНИЯ \\ КОРОНАВИРУСНОЙ ИНФЕКЦИИ \\ В МНОГОКВАРТИРНЫХ ДОМАХ}

\section{THE ROLE OF MANAGEMENT ORGANIZATIONS IN CARRYING OUT SANITARY AND ANTI-EPIDEMIOLOGICAL MEASURES TO PREVENT THE SPREAD OF CORONAVIRUS INFECTION IN APARTMENT BUILDINGS}

Аннотация:

В статье представлен анализ санитарно-противоэпидемиологических мероприятий по предупреждению распространения коронавирусной инфекции (COVID-19) организациями, осуществляющих предпринимательскую деятельность по управлению многоквартирными домами на территории Российской Федерации. Рассмотрены статистические показатели распространения COVID-19 (заболеваемость и смертность) в России и в мире, правовые основы обеспечения благоприятного и безопасного проживания граждан в многоквартирных домах и наметившиеся тенденции на рынке жилищно-коммунальных услуг, активно освещаемые в российских средствах массовой информации. Выдвигается предположение о том, что в период активной борьбы с распространением COVID-19 в Pосcиu одну из ключевых ролей сыграют именно управляющие организации, деятельность которых в том числе должна быть направлена на поддержание здоровья граждан и благополучие населения в целом в условиях пандемии.

Ключевые слова:

многоквартирный дом, управляющая организация, санитарно-противоэпидемиологические мероприятия, благополучие населения, здоровье граждан, пандемия, карантин, самоизоляция, коронавирус, COVID-19.
Summary:

The article presents an analysis of sanitary and anti-epidemiological measures to prevent the spread of coronavirus infection (COVID-19) by organizations engaged in entrepreneurial management of apartment buildings in the Russian Federation. Statistical indicators of the distribution of COVID-19 (incidence and mortality) in Russia and in the world, the legal framework for ensuring a favorable and safe living of citizens in apartment buildings and emerging trends in the housing and communal services market, which are actively covered in the Russian media, are examined. It is suggested that during the period of an active fight against the spread of coronavirus infection in Russia, one of the key roles will be played by the managing organizations, whose activities should also be aimed at maintaining the health of citizens and the well-being of the population as a whole in a pandemic.
Keywords: apartment building, management organization, sanitary and anti-epidemiological measures, well-being of people, health of citizens, pandemic, quarantine, self-isolation, coronavirus, COVID-19.

Управление многоквартирным домом (МКД), что предписано Жилищным кодексом Российской Федерации, должно обеспечивать благоприятные и безопасные условия проживания граждан. Надлежащее содержание общего имущества в МКД должно осуществляться в соответствии с требованиями законодательства РФ, в том числе в области обеспечения санитарно-эпидемиологического благополучия населения и должно обеспечивать безопасность жизни и здоровья граждан [1]. В соответствии с санитарно-эпидемиологическими требованиями к условиям проживания в жилых зданиях и помещениях при эксплуатации жилых помещений требуется «проводить мероприятия, направленные на предупреждение возникновения распространения инфекционных заболеваний, связанных с санитарным состоянием жилого здания» [2].

Подобные положения жилищного законодательства РФ начали представлять особую значимость в управлении МКД в 2020 г., когда Россия оказалась перед лицом угрозы распространения коронавирусной инфекции, впервые зарегистрированной 31 декабря 2019 г. в Китае (г. Ухань) и охватившей уже большинство других стран. Целесообразно отметить, что до вспышки инфекции о новом вирусе и заболевании ничего не было известно [3]. 11 марта 2020 г. Всемирная организация здравоохранения (ВО3) официально объявила пандемию коронавируса во всем мире.

По данным на 7 апреля 2020 г. общее количество зараженных во всем мире составило 1348661 человек, из которых выздоровели 21,12 \% (284 882 человека), погибли - 5,54 \% (74 777 
человек). В России было выявлено 6352 случая заражения, 433 человека из которых выздоровели, 52 - погибли [4]. При этом, по данным Министерства здравоохранения РФ, 758401 человек прошел тест на коронавирус [5].

Особенностью распространения COVID-19 является то, что при кашле или чихании больного мелкие капли, выделяемые из носа или рта, попадают на окружающие предметы и поверхности. Это чрезвычайно важно для понимания при управлении МКД - люди на пути домой нередко берутся за перила и поручни крылец и лестничных маршей, ручки входных и тамбурных дверей, нажимают на кнопки вызова лифрта и нужного этажа и т. п. Такие поверхности в случае наличия в МКД зараженного коронавирусной инфекцией могут представлять опасность для всех остальных жителей дома.

Управляющие организации (УО) должны приложить все усилия, чтобы санитарная обработка мест общего пользования осуществлялась с применением дезинфицирующих средств, а вышеперечисленные поверхности протирались ежедневно, несмотря на состав и периодичность подобных работ, утвержденных собственниками на общем собрании. Определенную опасность представляет мусоропровод, которым, как правило, оборудованы 9-этажные и МКД более высокой этажности. Ежедневная протирка ручек загрузочных клапанов также должна стать частью санитарно-противоэпидемиологических мероприятий. Такой же позиции придерживается Министерство строительства и жилищно-коммунального хозяйства РФ, давшее в конце марта УО соответствующие рекомендации [6].

Придомовые детские площадки и спортивные городки представляют не меньшую опасность в первую очередь для детей и подростков. УО целесообразно ограничить посещаемость подобных мест общего пользования путем ограждения сигнальной лентой и размещения соответствующих уведомлений и (или) объявлений.

Особое внимание желательно уделить высотным МКД, в которых проживают сотни жителей города. Высокая проходимость первых этажей таких домов, повышенная частота эксплуатации лифтов, представляющих замкнутое пространство, и т.п. предъявляют дополнительные требования к проведению работ по поддержанию надлежащего санитарного состояния мест общего пользования. Кроме того, подобные дома зачастую оборудованы постом охраны или консьержслужбой - данные работники могут вести учет жильцов, нарушающих режим самоизоляции или карантин (если он был введен).

Чрезвычайно важно соблюдение УО требований охраны труда. Во избежание распространения коронавирусной инфекции все работники обязаны соблюдать меры индивидуальной защиты - во время выполнения работ по обслуживанию общего имущества в МКД носить, помимо спецодежды, маски и очки, надевать перчатки. Некоторые российские исследователи в условиях пандемии коронавируса предлагают внедрять современные системы управления безопасностью труда, например, 5S, «которая позволит бережливо относиться к работнику и его здоровью» [7], что представляется актуальным и для сферы жилищно-коммунального хозяйства.

Другой существенной частью противоэпидемиологических мероприятий в МКД является информирование собственников о коронавирусной инфекции, симптомах, основных мерах предосторожности и профилактики, предлагаемых ВОЗ, Минздравом РФ, Федеральной службой по надзору в сфере защиты прав потребителей и благополучия человека РФ (Роспотребнадзор). На это уже указывают и российские исследователи [8].

Несмотря на то, что размещение подобной информации на досках объявлений, расположенных во всех подъездах МКД или в пределах земельного участка, на котором находится МКД, не предусмотрено «Правилами предоставления коммунальных услуг собственникам и пользователям помещений в многоквартирных домах и жилых домах» [9], складывающаяся неблагоприятная обстановка в РФ требует принятия всех возможных мер. Помимо размещения объявлений на досках, возможно индивидуальное информирование каждого из жителей МКД посредством почтовых ящиков.

Информирование жителей о COVID-19 может быть организовано УО через официальный сайт, а также группы собственников МКД в социальных сетях и мессенджерах (например, WhatsApp). При наличии технической возможности телефон аварийно-диспетчерской службы может быть оборудован автоинформатором с целью снижения нагрузки на операторов. Роль информационных систем в управлении МКД повышается кратно в условиях пандемии - в целях соблюдения режима самоизоляции или карантина собственники не должны проводить общие собрания путем совместного присутствия (очно), а также обходить квартиры в ходе заочного голосования, что таким образом вынуждает проводить голосования с использованием всевозможных компьютерных программ и онлайн-сервисов.

Информирование жителей - задача не только УО. Советы МКД, старшие по домам и подъездам также должны принимать активное участие в данной работе. Как правило, именно эти 
люди в первую очередь узнают о тех или иных событиях, происходящих в их доме. В тесном взаимодействии с УО инициативные жители помогут вовремя выявить заболевших коронавирусом, проинформировать соседей и соответствующие службы и принять дальнейшие меры по противодействию распространению заболевания.

Немаловажную роль УО могут сыграть в обеспечении режима самоизоляции или карантинных мероприятий в пределах одного или нескольких домов, особенно если территория МКД огорожена, все калитки и двери имеют запорные устройства (в том числе оборудованы системой коллективного управления доступом). Ведь один из основных принципов самоизоляции в домашних условиях, предложенных Роспотребнадзором, - это «не выходить из дома весь период карантина, даже для того, чтобы получить посылку, купить продукты или выбросить мусор» [10].

Как отмечает глава экспертной группы по сдерживанию и противоэпидемическому контролю на уровне микрорайонов Центральной руководящей группы в провинции Хубэй У Хао (Китай), «жилые микрорайоны - это первая линия противоэпидемической работы во всей системе локализации и противоэпидемического контроля». Специалистами группы были разработаны следующие рекомендации, которые применимы и для российских МКД и не могут быть реализованы без участия УО: переход домов на закрытый режим, где всем входящим и выходящим измеряют температуру; сортировка и дезинфекция коммунальных отходов тех, кто находится на карантине [11].

Однако на сегодняшний день УО не уполномочены вводить карантин в управляемом МКД это компетенция Роспотребнадзора. Тем не менее в РФ уже имеются подобные прецеденты [12] и действия УО в данном случае представляются вполне оправданными с учетом норм жилищного законодательства и необходимой оперативности в принятии безотлагательных мер.

Организации жилищно-коммунального хозяйства (ЖКХ) наравне с медицинскими организациями и организациями, осуществляющими неотложные работы в условиях чрезвычайных обстоятельств, находятся в числе непрерывно действующих организаций, на которые не распространяются Указ Президента РФ от 25.03.2020 № 206 «Об объявлении в Российской Федерации нерабочих дней» и Указ Президента РФ от 02.04.2020 № 239 «О мерах по обеспечению санитарно-эпидемиологического благополучия населения на территории Российской Федерации в связи с распространением новой коронавирусной инфекции (COVID-19)» (о продлении нерабочих дней до 30 апреля 2020 г.). Исходя из этого, работники УО в состоянии при необходимости круглосуточно обеспечить проведение карантинных мероприятий.

Тем не менее не все специалисты отрасли ЖКХ готовы принять важность роли УО в проведении санитарно-противоэпидемиологических мероприятий. Так, исполнительный директор НП «ЖКХ Контроль» Разворотнева С.В. считает, «что нельзя ответственность за санитарное состояние МКД перекладывать исключительно на УК и ТСЖ, потому что их силами не получится обеззаразить дом полностью» [13].

В складывающейся ситуации в РФ представляются абсурдными предложения отменить квартплату на время эпидемии [14]. Несмотря на то, что вспышка коронавируса уже нанесла ущерб глобальной экономике [15] и международной торговле [16], произошло падение отечественного фондового рынка [17], что неизбежно отразится на финансовом благополучии многих россиян, своевременная оплата за жилищно-коммунальные услуги (ЖКУ) чрезвычайно важна для поддержания надлежащего функционирования УО и их участия в санитарно-противоэпидемиологических мероприятиях. Более того, целесообразно обеспечить дополнительную финансовую поддержку УО из федеральных и местных бюджетов для этих целей.

Тем не менее, в качестве помощи гражданам часть российских управляющих и ресурсоснабжающих организаций в регионах ввели механизмы рассрочки и временно отменили штрафы за несвоевременную оплату ЖКУ [18]. Подобная практика позднее была поддержана Правительством РФ - запрет на начисление пени может быть введен до 1 января 2021 г., а также возможно введение временного запрета на отключение коммунальных ресурсов неплательщикам [19]. Данная мера неплохой компромисс между полной отменой квартплаты и увеличением тарифов с целью компенсации возможного снижения неплатежей населением за ЖКУ. Кроме того, Правительством РФ был упрощен порядок получения субсидий на оплату жилого помещения и коммунальные услуги - до 1 октября 2020 г. гражданам предоставлена возможность автоматически продлевать получение субсидии без личного обращения в органы соцзащиты, что также представляется логичным [20].

Пандемия коронавируса COVID-19 представляет реальную угрозу глобальному здравоохранению по сравнению с предыдущими вспышками пневмоний [21] и бросает серьезный вызов устойчивому развитию всего мира [22]. Егоров А.В. подчеркивает, что «резонансная реакция на коронавирус связана не только с особенностями самого вируса, но и с накопившимися изменениями в обществе» [23].

Нет никаких сомнений, что в ближайшем будущем РФ в общем, и сектор ЖКХ в частности ждут большие перемены, в том числе и гражданско-правового характера [24]. Однако в период 
активной борьбы с распространением коронавирусной инфекции одну из ключевых ролей должны сыграть именно УО, которые призваны обеспечивать благоприятные и безопасные условия проживания граждан в МКД.

\section{Ссылки:}

1. Жилищный кодекс Российской Федерации [Электронный ресурс]. Доступ из справ.-правовой системы «КонсультантПлюс».

2. Об утверждении СанПиН 2.1.2.2645-10 [Электронный ресурс] : постановление Главного государственного санитарного врача РФ от 10.06.2010 № 64 : в ред. от 27.12.2010. Доступ из справ.-правовой системы «КонсультантПлюс».

3. Вопросы и ответы о коронавирусной инфекции COVID-19 [Электронный ресурс] // Всемирная организация здравоохранения. URL: https://www.who.int/ru/emergencies/diseases/novel-coronavirus-2019/advice-for-public/q-a-coronaviruses (дата обращения: 29.03.2020)

4. Подробная статистика по коронавирусу в России и мире [Электронный ресурc]. URL: https://coronavirus-monitor.ru/ (дата обращения: 07.04.2020).

5. Информация о новой коронавирусной инфекции [Электронный ресурс] // Министерство здравоохранения Российской Федерации. URL: https://www.rosminzdrav.ru/ministry/covid19 (дата обращения: 07.04.2020).

6. Минстрой рекомендует управляющим компаниям чаще дезинсицировать подъезды [Электронный ресурс] // ТАСС. URL: https://tass.ru/nedvizhimost/8084179 (дата обращения: 29.03.2020).

7. Актуальные аспекты обеспечения безопасности человека при коронавирусе / Е.Г. Шеметова, Д.Д. Шахова, А.К. Иванова [и др.] // Молодежь и наука: шаг к успеху. Сборник научных статей 4-й Всероссийской научной конференции перспективных разработок молодых ученых. В 5-ти томах. Курск. 2020. Т. 4. С. 209-212.

8. Романов Б.К. Коронавирусная инфекция COVID-19 // Безопасность и риск фармакотерапии. 2020. Т. 8. №1. С. 3-8. https://doi.org/10.30895/2312-7821-2020-8-1-3-8

9. О предоставлении коммунальных услуг собственникам и пользователям помещений в многоквартирных домах и жилых домов [Электронный ресурс] : постановление Правительства РФ от 06.05.2011 № 354 : в ред. от 13.07.2019). Доступ из справ.-правовой системы «КонсультантПлюс»

10. COVID-19 Коронавирус. Информация для граждан [Электронный ресурс] // Федеральная служба по надзору в сфере защиты прав потребителей и благополучия человека. URL: https://www.rospotrebnadzor.ru/about/info/news_time/news_details.php?ELEMENT_ID=13566 (дата обращения: 29.03.2020).

11. «Китайский опыт» в противостоянии эпидемии нового коронавируса [Электронный ресурс] // PИA Hовости. URL: https://ria.ru/20200323/1568997840.html (дата обращения: 29.03.2020).

12. На карантин из-за коронавируса закрылась целая многоэтажка в Екатеринбурге. Вот только это незаконно [Электронный ресурc] // Medialeaks. URL: https://medialeaks.ru/news/2403vzn-dom-na-karantine/ (дата обращения: 29.03.2020).

13. В борьбу с коронавирусом в России включились коммунальные компании [Электронный ресурс] // PИA Hoвости. URL: https://realty.ria.ru/20200316/1568685523.html (дата обращения: 29.03.2020).

14. Отменят ли квартплату на время коронавируса [Электронный ресурс] // Свободная Пресca. URL: https://svpressa.ru/society/article/260718/ (дата обращения: 29.03.2020).

15. Морозов С.А. Каким будет ущерб от вспышки коронавируса для глобальной экономики? // Научный электронный журнал Меридиан. 2020. № 8 (42). С. 456-458.

16. Долгов С.И., Савинов Ю.А. Влияние вспышки нового коронавируса на международную торговлю // Российский внешнеэкономический вестник. 2020. № 2. С. 7-18.

17. Шиков П.А. Падение отечественного фондового рынка на фоне распространения эпидемии коронавируса // Научный электронный журнал Меридиан. 2020. № 9 (43). С. 553-555.

18. Пени на себя: УК в регионах временно отменят штрафы за неуплату ЖКУ [Электронный ресурс] // Известия. URL: https://iz.ru/991481/mariia-perevoshchikova/peni-na-sebia-uk-v-regionakh-vremenno-otmeniat-shtrafy-za-neuplatu-zhku (дата обращения: 29.03.2020).

19. Правительство отменило пени за неоплату жилищно-коммунальных услуг [Электронный ресурс] // Beдомости. URL: https://www.vedomosti.ru/business/articles/2020/04/05/827191-peni-peni-za-neoplatu (дата обращения: 04.04.2020).

20. О внесении изменений в Правила предоставления субсидий на оплату жилого помещения и коммунальных услуг и об особенностях предоставления субсидий на оплату жилого помещения и коммунальных услуг до 1 октября 2020 г. : постановление Правительства РФ от 02.04.2020 N 420. Доступ из справ.-правовой системы «КонсультантПлюс».

21. Вспышка нового инфекционного заболевания COVID-19: ß-коронавирусы как угроза глобальному здравоохранению / Д.В. Горенков, Л.М. Хантимирова, В.А. Шевцов [и др.] // Биопрепараты. Профилактика, диагностика, лечение. 2020. № 1. С. 6-20.

22. Пецерица В.Ф. Коронавирус - вызов устойчивому развитию всего мира и борьба с ним в Китае // Трансграничная экономика. 2020. № 1. С. 5.

23. Егоров А.В. Экономика эпидемий // Банковское дело. 2020. № 3. С. 7-11.

24. Филиппова С.Ю. О текущей ситуации с точки зрения теории юридического факта: гражданско-правовые последствия коронавируса, изменения курса валют, политико-правовых решений органов государственной власти // Хозяйство и право. 2020. № 4 (519). С. 47-61.

Редактор: Мамлиева Лилия Нурихановна Переводчик: Кочетова Дарья Андреевна 